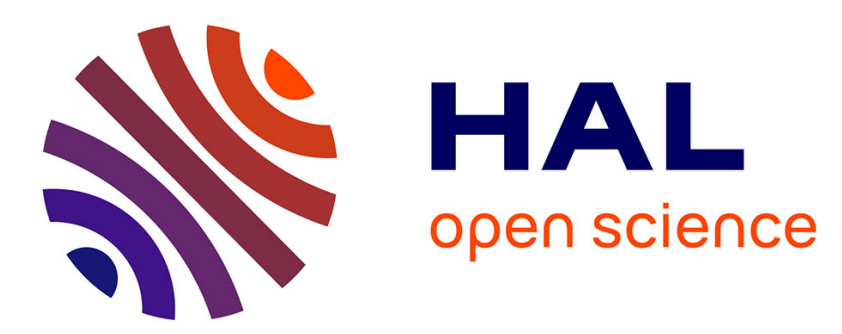

\title{
Tracking metal evolution in arc magmas: Insights from the active volcano of La Fossa, Italy
}

Simone Costa, Paolo Fulignati, Anna Gioncada, Marco Pistolesi, Delphine Bosch, Olivier Bruguier

\section{- To cite this version:}

Simone Costa, Paolo Fulignati, Anna Gioncada, Marco Pistolesi, Delphine Bosch, et al.. Tracking metal evolution in arc magmas: Insights from the active volcano of La Fossa, Italy. Lithos, 2020, pp.105851. 10.1016/j.lithos.2020.105851 . hal-02991253

\section{HAL Id: hal-02991253 \\ https://hal.science/hal-02991253}

Submitted on 16 Nov 2020

HAL is a multi-disciplinary open access archive for the deposit and dissemination of scientific research documents, whether they are published or not. The documents may come from teaching and research institutions in France or abroad, or from public or private research centers.
L'archive ouverte pluridisciplinaire HAL, est destinée au dépôt et à la diffusion de documents scientifiques de niveau recherche, publiés ou non, émanant des établissements d'enseignement et de recherche français ou étrangers, des laboratoires publics ou privés. 


\title{
Tracking metal evolution in arc magmas: Insights from the active volcano of La Fossa, Italy
}

\author{
Simone Costa ${ }^{\mathrm{a}, \mathrm{b}}$, Paolo Fulignati $^{\mathrm{b}, *}$, Anna Gioncada $^{\mathrm{b}}$, Marco Pistolesi $^{\mathrm{b}}$, Delphine Bosch ${ }^{\mathrm{c}}$, Olivier Bruguier $^{\mathrm{c}}$ \\ a Dipartimento di Scienze della Terra, Università di Firenze, via La Pira, 4, 50121 Firenze, Italy \\ b Dipartimento di Scienze della Terra, Università di Pisa, via S. Maria, 53, 56126 Pisa, Italy \\ c Géosciences Montpellier, Université de Montpellier, CNRS, Place E. Bataillon, 34095 Montpellier, France
}

\begin{abstract}
A B S T R A C T
The mineralization potential of arc magmas depends, among other factors, on the timing of sulfide melt saturation relative to magma differentiation and to exsolution of a magmatic fluid phase. In fossil mineralized or barren systems, understanding the evolution of metals along the magma differentiation path is often hindered by late magmatic processes and hydrothermal alteration. To better understand the process of metal evolution "caught in the act" in crustal reservoirs, we analyzed magmatic sulfides and melt inclusions found within eruptive products from the active arc volcano, La Fossa (Vulcano Island, Italy), for the basalt to rhyolite compositional spectrum. We found that, in case of sulfide-undersaturated and volatile-rich arc basalts, metals are scarcely subtracted by degassing during ascent to shallow crustal reservoirs and reach the highest abundances in intermediate magmas ( $250 \mathrm{ppm} \mathrm{Cu}$ ). At sulfide saturation the sulfide melt has $34-66 \mathrm{wt} \% \mathrm{Cu}$, leading to a dramatic decrease in chalcophile metals dissolved in the silicate melt. After fractionation of only $0.2-0.3 \mathrm{wt} \%$ of sulfide in the solid assemblage, the exsolved sulfide is a monosulfide solid solution (pyrrhotite) containing $<3 \mathrm{wt} \% \mathrm{Cu}$. Metals that do not partition in sulfides $(\mathrm{Pb}, \mathrm{Zn})$ increase their concentrations during magmatic evolution until they are sequestered by a $\mathrm{Cl}$-rich aqueous fluid phase exsolved at the rhyolitic stage. The absolute and $\mathrm{Cu}$-normalized concentrations of metals in sulfide inclusions are similar to sulfide accessories in magmatic rocks associated with world-class porphyry $\mathrm{Cu}$ systems. Our results demonstrate that the mechanisms governing metal evolution inferred for the magmatic stage in porphyry Cu environments can be also tracked at an active arc volcano, using eruptive products as snapshots of the magmatic evolution. Arc volcanoes can thus be viewed as ideal active analogues when studying these crucial processes for the formation of porphyry Cu deposits.
\end{abstract}

\section{Introduction}

Metal evolution in arc magmas is difficult to constrain due to the loss of volatiles and the loss of metals during crystallization and because, in most cases, magmas become saturated in sulfides at some stage during their evolution (Audétat and Simon, 2012). Indeed, due to the strong affinity of chalcophile and siderophile elements (e.g., Platinum-Group Elements, $\mathrm{Cu}, \mathrm{Au}$, and $\mathrm{Ag}$ ) for the sulfide phase, sulfides exsolved from silicate magmas lead to severe metal depletion in the residual silicate melt (Park et al., 2015).

A primary control on metal evolution in arc magmas is exerted by: 1 ) the timing of sulfide saturation relative to magmatic differentiation and volatile exsolution; 2 ) the amount of metal segregated into magmatic sulfides; 3 ) the amount of sulfide formed; 4) and whether sulfides are 'irretrievably lost' or may instead release metals again at later stages (Bai et al., 2020; Chang and Audétat, 2018; Halter et al., 2005; Hao et al.,
2019; Mungall et al., 2015; Park et al., 2015, 2019; Wilkinson, 2013; Zhang and Audétat, 2017). The combined role of these factors has proven difficult to resolve, largely because of the complexity in measuring the metal content of the magmas during their evolution (Park et al., 2019). Information mostly derives from the roots - sulfidebearing cumulates - of their plumbing system or from the mineralized bodies (Chang and Audétat, 2018; Chen et al., 2020). As magmatichydrothermal ore deposits can be considered the extinct equivalent of active magmatic systems (Hedenquist and Lowenstern, 1994), the investigation of these processes in the products of active arc volcanoes, particularly with the support of data from silicate melt inclusions, can provide pivotal information on metal budget and ore genetic models associated with arc-related magmas. A significant advantage in studying active volcanic systems is the lack of hydrothermal alteration or mineralization overprints, as shown by recent works for magmatic sulfide saturation studies (Fulignati et al., 2018; Georgatou et al., 2018; Georgatou and Chiaradia, 2020; Nadeau et al., 2010; Zelenski et al., 2018). Despite that, very few works have tackled the investigation of metal evolution through the processes of magma differentiation, sulfide exsolution 
and fluid exsolution at active volcanoes or across the wide compositional spectra of magma types (Cox et al., 2019; Park et al., 2013, 2015; Timm et al., 2012).

La Fossa volcano (Italy) is an ideal site to study mineralizing processes beneath arc volcanoes, being characterized by an active magmatic-hydrothermal system (Boyce et al., 2007; Fulignati et al., 1998) and providing evidence of sulfide melt-silicate melt immiscibility (Fulignati et al., 2018). Here we use melt inclusions, magmatic sulfides and host minerals to track the evolution of metals for the entire basalt to rhyolite compositional spectrum. The suite belongs to a shoshonitic to potassic series in a subduction setting, similar to part of the magma types found in association with porphyry $\mathrm{Cu}$ deposits (Audétat and Simon, 2012; Sillitoe, 2010). Moreover, we compare our results to metal contents in sulfides from magmatic systems associated with ore deposits, showing that strong analogies exist between metal evolution in active arc volcanoes and those reported for porphyry $\mathrm{Cu}$ environments.

\section{Geological background}

La Fossa is the active volcanic center of Vulcano Island, in the Aeolian archipelago, a continental volcanic arc located in southern Tyrrhenian Sea (Fig. 1a, b). The volcanic activity of the island started at $130 \mathrm{ka}$ with high-K calcalkaline (HKCA), shoshonitic (SHO) and, recently, potassic (KS) magmas (De Astis et al., 2000), showing the entire range in composition from basalt to rhyolite (Fig. 1c, d). The plumbing system of La Fossa is polybaric, dominated by fractional crystallization, crustal assimilation and magma mixing processes (Costa et al., 2020; De Astis et al., 2013; Peccerillo et al., 2006). These occur in a shoshonitic to latitic magma chamber at about $15 \mathrm{~km}$ deep, fed by shoshonitic basaltic magmas, and in shallower and smaller trachytic to rhyolitic reservoirs at 5-2 km deep (Costa et al., 2020; De Astis et al., 2013; Fulignati et al., 2018). Basaltic magmas have been only erupted at about $50 \mathrm{ka}$. They are $\mathrm{H}_{2} \mathrm{O}$-rich (water up to 5 wt\%; Le Voyer et al., 2014) and oxidized. La Fossa has been quiescent since $1890 \mathrm{CE}$, with a high temperature fumarolic field fed by magmatic and hydrothermal fluids (Paonita et al., 2013). A similar hydrothermal system was active in the past, as testified by hydrothermally altered lithics found in the eruptive products of recent (post-1000 CE) eruptions (e.g. Breccia di Commenda eruption; Fulignati et al., 1998; Gurioli et al., 2012; Rosi et al., 2018).

\section{Materials and analytical methods}

Samples were selected to ensure that the entire range of magma types, from basalt to rhyolite, was included in this study. They were analyzed for the composition of their sulfide (SIs) and melt (MIs) inclusions hosted within phenocrysts. Samples were preferentially selected from explosive eruptions, targeted to ensure quenching of melt inclusions to a glass with the eruption. This minimizes the potential for post-entrapment crystallization of microlites in the trapped melt or crystallization of the host mineral on the inclusion walls. They include scoriaceous lapilli of La Sommata and Vulcanello, of basaltic and shoshonitic composition, respectively. The latitic, trachytic and rhyolitic samples are represented by the Palizzi eruptive period of La Fossa and consist of dark grey coarse ash of Pal A (latite) and Pal C (latite, trachyte), pumiceous lapilli of Pal D (trachyte) and Pal B (rhyolite), and the Palizzi lava flow (trachyte) (see De Astis et al., 2013 and Di Traglia et al., 2013 for further information on volcanic stratigraphy). Lapilli were crushed and crystals were hand-picked under a stereomicroscope, embedded in epoxy resin mounts and polished. Slices of the Palizzi lava flow sample were also prepared in epoxy resin mounts for petrographic investigations and microanalyses. The polished resin mounts were first studied under reflected light with a petrographic microscope at the Dipartimento di Scienze della Terra at the Università di Pisa. Melt and sulfide inclusions were identified for the analytical follow-up. To avoid post-entrapment modifications of the melt composition due to melt crystallization or leakage, the selected melt inclusions are entirely glassy (no microlites) and lack large vapor bubbles or other evidence of only partial enclosing by the host crystal. Shrinkage bubbles are absent or small in Vulcanello MIs while they are common in La Sommata basalt and in Palizzi trachyte; bubbles may host traces of volatile elements escaped from melt, but the observation that they are apparently empty means that we can consider their metal content negligible. Based on the inspection of MIs under back-scattered electron (BSE) microscopy and on their major element composition, post-entrapment crystallization of the host on the inclusion walls can also be considered negligible with respect to chalcophile metals. This is in agreement with previous estimates $(<2 \mathrm{wt} \%)$ of olivine host crystallization for Vulcanello MIs (Fusillo et al., 2015), corresponding to a variation of the $\mathrm{Cu}$ content within analytical uncertainty.

After carbon-coating, backscattered electron images and the major element chemical composition of sulfide and melt inclusions were obtained with a Quanta 450 Field Emission-Scanning Electron Microscope (FE-SEM) (15 kV accelerating voltage, $10 \mathrm{~mm}$ working distance and $0.1 \mathrm{nA}$ ) equipped with Bruker microanalytical EDS system QUANTAX installed at the Centro Interdipartimentale di Scienza e Ingegneria dei Materiali (CISIM) at the Università di Pisa. Major and minor element compositions for each melt inclusion were also characterized using an electron probe microanalyzer (EPMA) JEOL JXA-8200, operating in wavelength dispersive mode with a defocused beam of $5 \mu \mathrm{m}(15 \mathrm{kV}$ accelerating voltage and $5 \mathrm{nA}$ beam current) at the Dipartimento di Scienze della Terra at the Università di Milano.

The bulk major element compositions of the texturally nonhomogeneous sulfide inclusions were reconstructed using spot analyses on the various sulfide phases present within each exposed sulfide inclusion. The reconstructed bulk composition was calculated dependent on the relative area percent of each sulfide phase, in the BSE images. Area percentages were determined using the image processing software package ImageJ (Image Processing and Analysis in Java, http://rsb.info. nih.gov/ij/) and the 2D images were segmented by manual thresholding. The uncertainty on the reconstructed bulk composition, involving both instrumental analytical error and manual image thresholding error, was evaluated to be $<10 \%$.

Trace element analyses of melt and sulfide inclusions and of host minerals were performed in situ by laser ablation inductively coupled plasma mass spectrometry (LA-ICPMS) at Géosciences Montpellier (Université de Montpellier, AETE-ISO regional facility of the OSU OREME), with a pulsed $193 \mathrm{~nm}$ ArF excimer laser (Analyte G2 from Teledyne) coupled to a Thermofinnigan Element XR mass spectrometer. For the analyses of host minerals, the laser was operated at a repetition rate of $8 \mathrm{~Hz}$ using spot sizes of 85 and $110 \mu \mathrm{m}$ and a $6 \mathrm{~J} / \mathrm{cm}^{2}$ energy density. Total analysis time was $120 \mathrm{~s}$ with the first $80 \mathrm{~s}$ used for the background measurement and the last $40 \mathrm{~s}$ for sample ablation. Synthetic glass NIST 612 was used for external calibration. For melt inclusions, the laser was operated at a repetition rate of $6 \mathrm{~Hz}$ using spot sizes of 10 to $20 \mu \mathrm{m}$ and a $6 \mathrm{~J} / \mathrm{cm}^{2}$ energy density. Total analysis time was $120 \mathrm{~s}$ with the first $80 \mathrm{~s}$ used for background measurement and the last $40 \mathrm{~s}$ for sample ablation. Synthetic glass NIST 610 was used for external calibration. For minerals and glass inclusions the accuracy of the analyses was monitored using the standard glass BIR- 1 and $\mathrm{SiO}_{2}$ of each mineral/glass, used as internal standard. For sulfide inclusions, only those where their exposed diameter was $>15 \mu \mathrm{m}$ were analyzed. The beam spot sizes were 5 to $10 \mu \mathrm{m}$. Only two non-homogeneous (polymineralic) sulfide inclusions were sufficiently large to be analyzed; the laser spot was tuned to approximate the "bulk" composition of the sulfide inclusion, without distinguishing among the single sulfide phases. The laser was operated at a repetition rate of $6 \mathrm{~Hz}$ using and a $6 \mathrm{~J} / \mathrm{cm}^{2}$ energy density with a total analysis time of $240 \mathrm{~s}$ ( $200 \mathrm{~s}$ for background measurement and $40 \mathrm{~s}$ of sample analysis). The Synthetic standard MASS-1 was used for external calibration. $\mathrm{FeO}$ (measured $\mathrm{FeO}$, in the case of homogeneous sulfide inclusions, and $\mathrm{FeO}$ reconstructed with the above described procedure, in the case of non-homogeneous 
polymineralic sulfide inclusions) was used as an internal standard. Data reduction for the mineral, melt and sulfide inclusion was performed with the software package Glitter (http://www.glitter-gemoc.com). Detection limits, results of reference materials and control standard analysis are provided in the Supplementary Material S1.

\section{Results}

\subsection{Sulfide inclusions}

Based on their textures (polymineralic and homogeneous), two types of sulfide inclusions (Type 1 SIs, polymineralic and Type 2 SIs, homogeneous) were identified in the Vulcano products. Both types are spherical when found in glass, and spherical or ovoid to elongated in shape when enclosed in host phenocrysts, with shape partially defined by surrounding crystal growth (Fig. 2a).

Type 1 SIs (17 inclusions) are between 1 and $20 \mu \mathrm{m}$ in diameter (mostly $<10 \mu \mathrm{m}$ ) and consist of two or three Cu-rich sulfide phases each (Fig. 2a). These SIs are hosted in clinopyroxene, magnetite and feldspars (Fig. 2b). The composition of Type 1 sulfides (Table 1), when plotted in a Cu-Fe-S diagram at $1000{ }^{\circ} \mathrm{C}$ (Fig. 2c), spans from bornite solid solution (bnss) to the sulfide liquid field $(S L)$. The reconstructed bulk composition of these unmixed SIs ranges from $66 \mathrm{wt} \%$ to $34 \mathrm{wt} \% \mathrm{Cu}$ in the Cu-Fe-S diagram (Fig. 2c). Trace elements were measured up to $493 \mathrm{ppm} \mathrm{Ni,} 131 \mathrm{ppm} \mathrm{Co}$, 1145 ppm Zn, 397 ppm As, 208 ppm Se, 354 ppm Ag and 2020 ppm $\mathrm{Pb}$ (Table 2) within the two Type 1 SIs analyzed (which contained 65 and $46 \mathrm{wt} \% \mathrm{Cu})$.

Type 2 SIs (59 inclusions) are 5-60 $\mu \mathrm{m}$ in diameter with a mean size of $20 \mu \mathrm{m}$ and homogeneous textures (Fig. 2a); they occur in clinopyroxene, olivine, Ti-magnetite, plagioclase, sanidine, biotite and glass and prevail in mafic phases and glass. Type 2 SIs plot, at $1000{ }^{\circ} \mathrm{C}$, in the pyrrhotite field (mss, monosulfide solid solution), with Cu content up to $2.6 \mathrm{wt} \%$ (Fig. 2c; Table 1). If compared to Type 1 SIs, they show markedly higher Ni and Co contents, up to 3495 ppm and 4248 ppm, respectively, similar $\mathrm{Zn}$ and lower $\mathrm{Pb}$ (up to $385 \mathrm{ppm}$ ), with Ag and Se, in

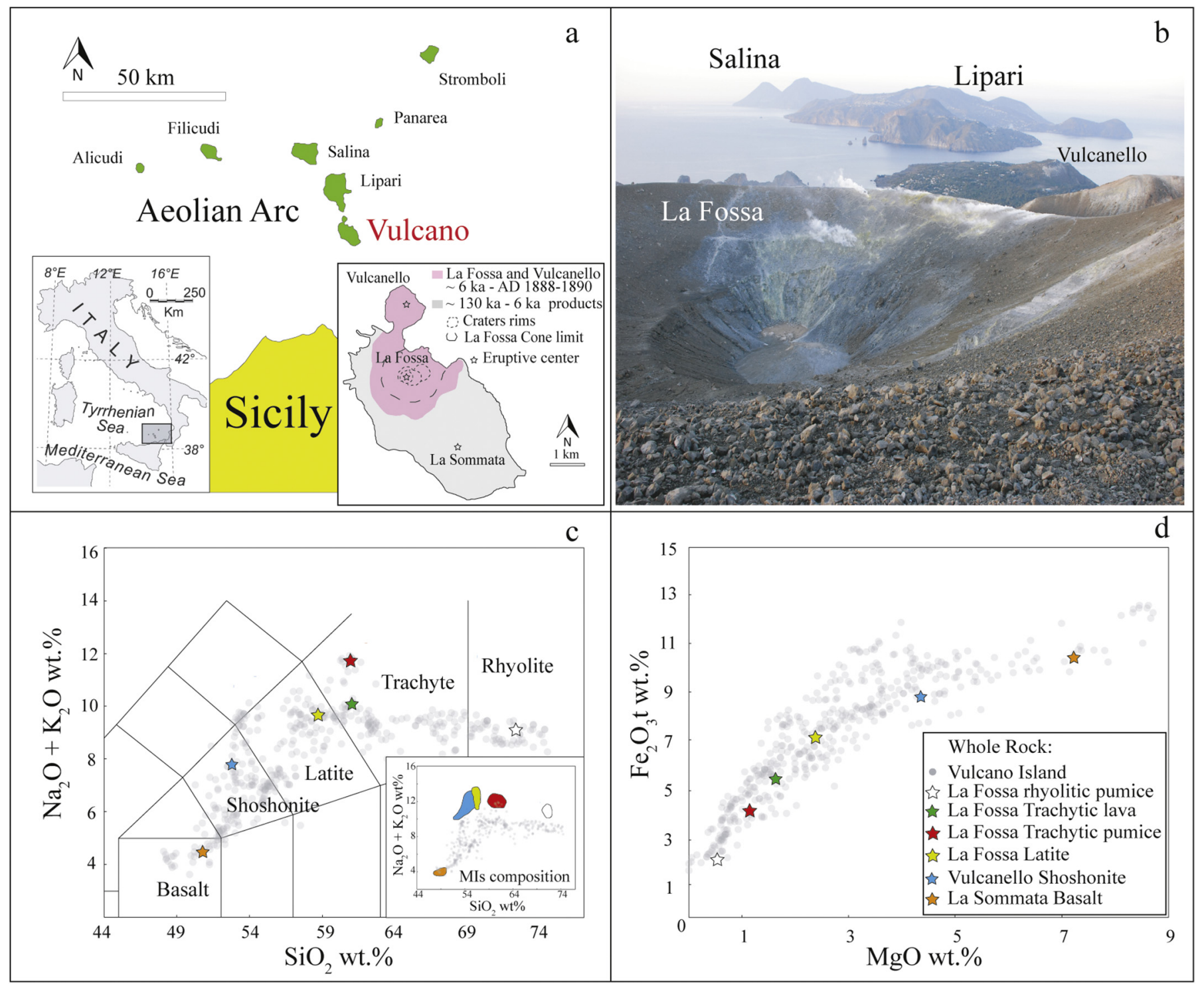

Fig. 1. (a) Location of La Fossa volcano and Vulcano island in the Aeolian Arc; (b) Panoramic view toward $\mathrm{N}$ of La Fossa crater and its fumarolic field; (c) TAS (total alkali vs SiO ${ }_{2}$ ) diagram of Vulcano rocks. Stars are the samples selected to represent the basalt to rhyolite suite; insert in (c) shows the composition of MIs of the selected samples; (d) Fe $\mathrm{O}_{3}$ tot. vs $\mathrm{MgO}$ diagram of Vulcano products. Whole rock data in (c) and (d) are re-calculated to 100 on anhydrous basis; literature data are from De Astis et al. (2013), Fusillo et al. (2015) and Costa et al. (2020). Melt inclusions major elements data are from Gioncada et al. (1998), Le Voyer et al. (2014), Fusillo et al. (2015), Fulignati et al. (2018) and this work. The complete data set of MIs is reported in the supplementary material S1. 


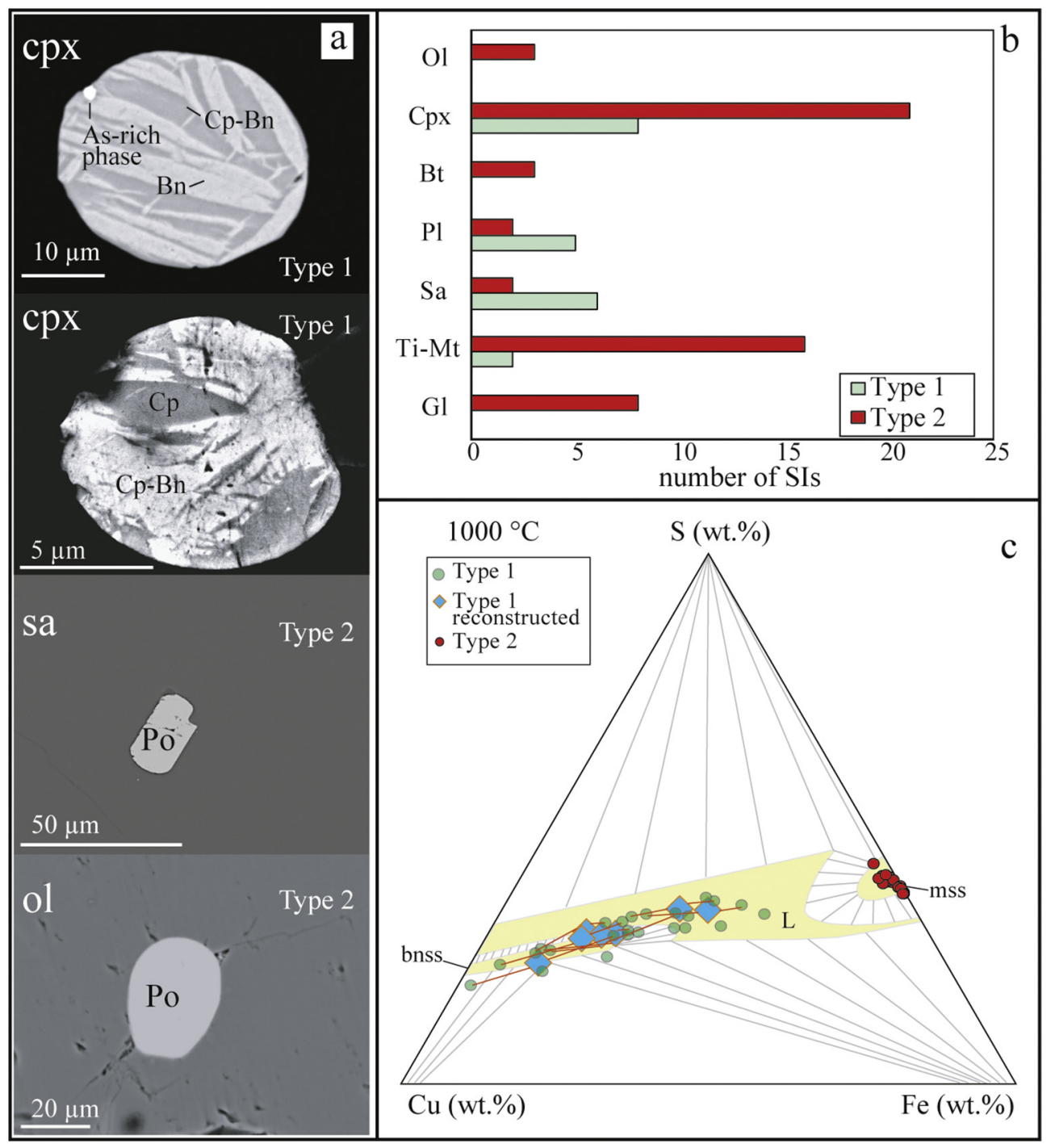

Fig. 2. (a) BSE images of Type 1 SIs consisting of unmixed chalcopyrite ( $\mathrm{Cp}$ )-bornite (Bn) and Type 2 SIs represented by homogeneous pyrrhotite (Po); (b) abundance of SIs in the various mineral phases and groundmass glass of eruptive products (Ol: olivine; Cpx: clinopyroxene; Bt: biotite; Pl: plagioclase; Sa: sanidine; Mt.: magnetite; Gl: groundmass glass); (c) Composition of SIs in the Cu-Fe-S system at $1000{ }^{\circ} \mathrm{C}$ (Craig and Kullerud, 1969), for Type 1 SIs analyses of unmixed phases and the correspondent reconstructed composition are shown and joined by red lines, error bars fall within the symbols; data from this work and Fulignati et al. (2018) are reported in Table 1 and in the supplementary material S1. L, liquid; bnss, bornite solid solution; mss, monosulfide solid solution. (For interpretation of the references to colour in this figure legend, the reader is referred to the web version of this article.)

the tens of ppm range. The only SI found in a rhyolite is pyrrhotite with $0.4 \mathrm{wt} \% \mathrm{Cu}$, characterized by very low $\mathrm{Zn}, \mathrm{Pb}$ and $\mathrm{Ag}$ and higher $\mathrm{Mo}$ contents (Tables 1 and 2).

Type 1 and Type 2 SIs are common accessories in trachytes, whereas they are extremely rare in latites (only Type 1 SIs) and in rhyolites (only Type 2 SIs), where just a couple of SIs were found after the inspection of several dozens of crystals. They are absent in basalt-shoshonite rocks. The two types of SIs never coexist in the samples of the same eruption. The entire dataset of analyses of the sulfides and hosts are reported in Tables 1 and 2 and Supplementary Material S1.

Some differences can be found when comparing the host mineral compositions for Type 1 and Type 2 SIs. Clinopyroxene (the most frequent host for both types of SIs; Fig. 2b) shows higher $\mathrm{Cu}, \mathrm{Cr}, \mathrm{V}$ and $\mathrm{Ni}$ contents for Type 1 sulfides compared to Type 2, for a similar Mg\# range (see Supplementary Material S1). This is confirmed also when comparing the entire clinopyroxene analytical dataset (Supplementary Material S1) for the Vulcano products hosting Type 1 and Type 2 SIs.

\subsection{Melt inclusions}

The composition of glassy MIs in olivine, clinopyroxene, plagioclase, sanidine and biotite found in the products of explosive eruptions of basaltic, shoshonitic, latitic, trachytic and rhyolitic magmas is assumed to be representative of the magmas spanning the whole La Fossa magmatic differentiation path (Fig. 1c, Table 3 and Supplementary Material S1). The differentiation trend involves the fractionation of olivine, clinopyroxene, Ti-magnetite, labradorite to andesine plagioclase and, in evolved magmas, sanidine, minor oligoclase and biotite (Gioncada et al., 1998). Ti-magnetite joins the fractionating assemblage early, as shown by the decrease of Fe with $\mathrm{Mg}$ (Fig. 1d), while apatite joins later in intermediate terms.

The $\mathrm{Cu}$ content of MIs reaches the highest values at intermediate compositions ( $\mathrm{Zr}$ around $160-200 \mathrm{ppm}$, at the latite-trachyte transition) and, when the highest $\mathrm{Cu}$ contents are considered, defines a trend that increases with magmatic differentiation from basalt $(\sim 50 \mathrm{ppm})$ to latite and trachyte ( $250 \mathrm{ppm})$, and then abruptly drops to $<60 \mathrm{ppm}$ (Fig. 3a). Low $\mathrm{Cu}$ values have also been measured in 
t1.1 Table 1

t1.2 Major element composition (wt\%) of Type 1 and Type 2 SIs; Ol: olivine; Cpx: clinopyroxene; Bt: biotite; Pl: plagioclase; Sa: sanidine; Ti-Mt: Ti-magnetite. Reconstructed: calculated bulk t1.3 composition of the sulfide inclusions (see methods section for details and supplementary materials for phase proportions); bdl: below detection limit; source a: Fulignati et al. (2018), t1.4 EPMA analyses; source b: this work, FE-SEM-EDS analyses.

\begin{tabular}{|c|c|c|c|c|c|c|c|c|c|c|c|c|c|c|}
\hline $\mathrm{t} 1.5$ & Host rock & Unit & Host mineral & Sulfide ID & Sulfide type & Source & $\mathrm{Fe}$ & S & Co & $\mathrm{Mn}$ & $\mathrm{Ni}$ & $\mathrm{Zn}$ & $\mathrm{Cu}$ & Total \\
\hline $\mathrm{t} 1.6$ & Trachyte & Pal D & sa & PAL-90 sulf1 & 2 & $\mathrm{a}$ & 58.48 & 37.19 & 0.09 & 0.08 & 0.06 & bdl & 1.44 & 97.33 \\
\hline $\mathrm{t} 1.7$ & Trachyte & Pal D & $\mathrm{cpx}$ & PAL-90 sulf2 & 2 & a & 59.12 & 38.05 & 0.03 & 0.09 & 0.03 & 0.10 & 1.19 & 98.60 \\
\hline $\mathrm{t} 1.8$ & Trachyte & Pal D & cpx & PAL-90 sulf2 & 2 & a & 59.89 & 38.08 & 0.07 & 0.12 & 0.05 & 0.03 & 0.42 & 98.65 \\
\hline $\mathrm{t} 1.9$ & Trachyte & Pal D & ol & pal90solf3 & 2 & a & 57.19 & 37.24 & 0.14 & 0.18 & 0.07 & 0.07 & 1.62 & 96.52 \\
\hline $\mathrm{t} 1.10$ & Trachyte & Pal D & gl & pal90solf4 & 2 & a & 58.01 & 37.24 & 0.16 & 0.11 & 0.09 & bdl & 2.32 & 97.93 \\
\hline $\mathrm{t} 1.11$ & Trachyte & Pal D & ol & pal90solf5 & 2 & $\mathrm{a}$ & 58.94 & 37.60 & 0.10 & 0.12 & 0.10 & bdl & 1.67 & 98.53 \\
\hline $\mathrm{t} 1.12$ & Trachyte & Pal D & ol & pal90solf5 & 2 & $\mathrm{a}$ & 59.19 & 38.08 & 0.09 & 0.18 & 0.04 & bdl & 1.29 & 98.88 \\
\hline $\mathrm{t} 1.13$ & Trachyte & Pal D & $\mathrm{gl}$ & pal90sulf8 & 2 & $\mathrm{a}$ & 57.09 & 38.05 & 0.07 & 0.10 & 0.04 & 0.11 & 1.34 & 96.80 \\
\hline $\mathrm{t} 1.14$ & Trachyte & Pal D & Ti-mt & pal90sulf10 & 2 & $\mathrm{a}$ & 58.72 & 38.24 & 0.05 & 0.16 & 0.05 & 0.05 & 0.97 & 98.23 \\
\hline $\mathrm{t} 1.15$ & Trachyte & Pal D & cpx & pal90sulf13 & 2 & $\mathrm{a}$ & 58.38 & 37.99 & 0.13 & 0.12 & 0.00 & 0.03 & 1.54 & 98.18 \\
\hline $\mathrm{t} 1.16$ & Trachyte & Pal D & cpx & pal90sulf13 & 2 & a & 58.25 & 37.70 & 0.07 & 0.04 & 0.01 & 0.06 & 1.46 & 97.58 \\
\hline $\mathrm{t} 1.17$ & Trachyte & Pal D & cpx & pal90sulf14a & 2 & a & 53.30 & 39.64 & 0.14 & 0.09 & 0.06 & bdl & 2.16 & 95.39 \\
\hline $\mathrm{t} 1.18$ & Trachyte & Pal D & Ti-mt & PAL90 u293sulf17 & 2 & a & 58.15 & 37.73 & 0.09 & 0.08 & 0.01 & bdl & 1.31 & 97.37 \\
\hline $\mathrm{t} 1.19$ & Trachyte & Pal D & Ti-mt & PAL90 u293sulf17 & 2 & $\mathrm{a}$ & 58.60 & 38.26 & 0.07 & 0.12 & 0.09 & 0.02 & 1.39 & 98.54 \\
\hline $\mathrm{t} 1.20$ & Trachyte & Pal D & $\mathrm{pl}$ & PAL90U297 sulf18 & 2 & a & 56.63 & 37.48 & 0.03 & 0.10 & 0.08 & 0.10 & 1.55 & 95.95 \\
\hline $\mathrm{t} 1.21$ & Trachyte & Pal D & cpx & PAL-15D sulf1 & 2 & $\mathrm{a}$ & 56.33 & 37.35 & 0.11 & 0.11 & 0.04 & bdl & 1.34 & 95.28 \\
\hline $\mathrm{t} 1.22$ & Trachyte & Pal D & cpx & PAL-15D sulf2 & 2 & $\mathrm{a}$ & 57.60 & 37.53 & 0.12 & 0.13 & 0.05 & bdl & 1.32 & 96.75 \\
\hline $\mathrm{t} 1.23$ & Trachyte & Pal D & Ti-mt & PAL-15D sulf3 & 2 & $\mathrm{a}$ & 56.48 & 37.45 & 0.13 & 0.12 & 0.05 & 0.04 & 1.34 & 95.60 \\
\hline $\mathrm{t} 1.24$ & Trachyte & Pal D & $\mathrm{gl}$ & PAL-15D sulf4 & 2 & $\mathrm{a}$ & 56.85 & 37.61 & 0.09 & 0.11 & 0.05 & 0.11 & 1.30 & 96.12 \\
\hline $\mathrm{t} 1.25$ & Trachyte & Pal D & $\mathrm{cpx}$ & sulf5 & 2 & a & 56.06 & 37.68 & 0.06 & 0.14 & 0.06 & bdl & 1.84 & 95.84 \\
\hline $\mathrm{t} 1.26$ & Trachyte & Pal D & cpx & pal15sulf8.spc & 2 & $\mathrm{a}$ & 57.15 & 37.63 & 0.04 & 0.13 & bdl & 0.04 & 1.02 & 96.00 \\
\hline $\mathrm{t} 1.27$ & Trachyte & Pal D & $\operatorname{cpx}$ & Pal 15 D sulf 6 & 2 & $\mathrm{a}$ & 56.28 & 37.64 & 0.08 & 0.10 & 0.05 & 0.06 & 2.51 & 96.71 \\
\hline $\mathrm{t} 1.28$ & Trachyte & Pal D & cpx & Pal 15 D sulf 6 & 2 & $\mathrm{a}$ & 56.35 & 37.64 & 0.14 & 0.12 & 0.11 & 0.11 & 2.54 & 97.01 \\
\hline $\mathrm{t} 1.29$ & Trachyte & Pal D & cpx & Pal 15 D sulf 6 & 2 & $\mathrm{a}$ & 56.40 & 37.67 & 0.15 & 0.01 & 0.07 & 0.07 & 2.72 & 97.09 \\
\hline $\mathrm{t} 1.30$ & Trachyte & Pal D & Ti-mt & Pal 15 D sulf 7 & 2 & $\mathrm{a}$ & 57.99 & 37.64 & 0.03 & 0.10 & 0.05 & 0.04 & 1.21 & 97.06 \\
\hline $\mathrm{t} 1.31$ & Trachyte & Pal D & Ti-mt & Pal 15 D sulf 8 & 2 & $\mathrm{a}$ & 57.96 & 37.57 & 0.12 & 0.11 & 0.08 & 0.04 & 1.58 & 97.46 \\
\hline $\mathrm{t} 1.32$ & Trachyte & Palizzi lava & $\mathrm{pl}$ & SC15-1_1 & 1 & b & 24.05 & 32.12 & bdl & bdl & bdl & bdl & 43.83 & 100.00 \\
\hline $\mathrm{t} 1.33$ & Trachyte & Palizzi lava & $\mathrm{pl}$ & SC15-1_1 & 1 & b & 38.65 & 33.84 & bdl & bdl & bdl & bdl & 27.51 & 100.00 \\
\hline $\mathrm{t} 1.34$ & Trachyte & Palizzi lava & $\mathrm{pl}$ & reconstructed *SC15-1_1 & 1 & b & 33.54 & 33.24 & bdl & bdl & bdl & bdl & 33.22 & 100.00 \\
\hline $\mathrm{t} 1.35$ & Trachyte & Palizzi lava & $\mathrm{pl}$ & SC15-1_2 & 1 & b & 21.84 & 31.58 & bdl & bdl & bdl & bdl & 46.58 & 100.00 \\
\hline $\mathrm{t} 1.36$ & Trachyte & Palizzi lava & $\mathrm{pl}$ & SC15-1_2 & 1 & b & 33.72 & 34.57 & bdl & bdl & bdl & bdl & 31.70 & 100.00 \\
\hline $\mathrm{t} 1.37$ & Trachyte & Palizzi lava & pl & reconstructed *SC15-1_2 & 1 & b & 28.50 & 33.25 & bdl & bdl & bdl & bdl & 38.25 & 100.00 \\
\hline $\mathrm{t} 1.38$ & Trachyte & Palizzi lava & cpx & SC15-1_3 & 1 & $\mathrm{~b}$ & 20.92 & 28.88 & bdl & bdl & bdl & bdl & 50.20 & 100.00 \\
\hline $\mathrm{t} 1.39$ & Trachyte & Palizzi lava & $\operatorname{cpx}$ & SC15-1_3 & 1 & b & 5.09 & 22.51 & bdl & bdl & bdl & bdl & 72.40 & 100.00 \\
\hline $\mathrm{t} 1.40$ & Trachyte & Palizzi lava & $\mathrm{cpx}$ & SC15-1_3 & 1 & b & 20.74 & 30.62 & bdl & bdl & bdl & bdl & 48.64 & 100.00 \\
\hline $\mathrm{t} 1.41$ & Trachyte & Palizzi lava & $\operatorname{cpx}$ & reconstructed *SC15-1_3 & 1 & b & 15.57 & 27.94 & bdl & bdl & bdl & bdl & 56.48 & 100.00 \\
\hline $\mathrm{t} 1.42$ & Trachyte & Palizzi lava & $\operatorname{cpx}$ & SC15-1_3b & 1 & $\mathrm{~b}$ & 21.60 & 23.91 & bdl & bdl & bdl & bdl & 54.49 & 100.00 \\
\hline $\mathrm{t} 1.43$ & Trachyte & Palizzi lava & $\operatorname{cpx}$ & SC15-1_3b & 1 & b & 12.40 & 21.58 & bdl & bdl & bdl & bdl & 66.02 & 100.00 \\
\hline $\mathrm{t} 1.44$ & Trachyte & Palizzi lava & $\mathrm{cpx}$ & SC15-1_4 & 1 & b & 37.20 & 29.81 & bdl & bdl & bdl & bdl & 32.99 & 100.00 \\
\hline $\mathrm{t} 1.45$ & Trachyte & Palizzi lava & $\mathrm{cpx}$ & SC15-1_4 & 1 & $\mathrm{~b}$ & 30.91 & 31.85 & bdl & bdl & bdl & bdl & 37.24 & 100.00 \\
\hline $\mathrm{t} 1.46$ & Trachyte & Palizzi lava & $\mathrm{pl}$ & SC15-1_5 & 1 & b & 10.02 & 25.69 & bdl & bdl & bdl & bdl & 64.29 & 100.00 \\
\hline $\mathrm{t} 1.47$ & Trachyte & Palizzi lava & $\mathrm{pl}$ & SC15-1_5 & 1 & b & 22.46 & 29.18 & bdl & bdl & bdl & bdl & 48.36 & 100.00 \\
\hline $\mathrm{t} 1.48$ & Trachyte & Palizzi lava & $\mathrm{pl}$ & reconstructed *SC15-1_5 & 1 & b & 20.64 & 28.67 & bdl & bdl & bdl & bdl & 50.69 & 100.00 \\
\hline $\mathrm{t} 1.49$ & Trachyte & Palizzi lava & $\mathrm{pl}$ & SC15-1_6 & 1 & b & 18.07 & 30.59 & bdl & bdl & bdl & bdl & 51.35 & 100.00 \\
\hline $\mathrm{t} 1.50$ & Trachyte & Palizzi lava & $\mathrm{pl}$ & SC15-1_6 & 1 & $\mathrm{~b}$ & 9.64 & 24.69 & bdl & bdl & bdl & bdl & 65.66 & 100.00 \\
\hline $\mathrm{t} 1.51$ & Trachyte & Palizzi lava & $\mathrm{pl}$ & reconstructed *SC15-1_6 & 1 & b & 15.62 & 28.88 & bdl & bdl & bdl & bdl & 55.50 & 100.00 \\
\hline $\mathrm{t} 1.52$ & Trachyte & Pal D & sa & SC_18_20c1 & 2 & b & 62.38 & 37.48 & bdl & bdl & bdl & bdl & 0.14 & 100.00 \\
\hline $\mathrm{t} 1.53$ & Trachyte & Pal D & sa & SC_18_20c2 & 2 & $\mathrm{~b}$ & 62.83 & 36.85 & bdl & bdl & bdl & bdl & 0.32 & 100.00 \\
\hline $\mathrm{t} 1.54$ & Trachyte & Pal D & sa & SC_18_20c3 & 2 & b & 62.18 & 37.21 & bdl & bdl & bdl & bdl & 0.60 & 100.00 \\
\hline $\mathrm{t} 1.55$ & Trachyte & Pal D & sa & SC_18_20c4 & 2 & b & 63.61 & 36.11 & bdl & bdl & bdl & bdl & 0.28 & 100.00 \\
\hline $\mathrm{t} 1.56$ & Trachyte & Pal D & $\mathrm{pl}$ & SC_18_20c5 & 2 & b & 63.70 & 36.20 & bdl & bdl & bdl & bdl & 0.10 & 100.00 \\
\hline t1.57 & Trachyte & Palizzi lava & Ti-mt & sc1824 11-12 & 1 & b & 24.18 & 28.79 & bdl & bdl & bdl & bdl & 47.04 & 100.00 \\
\hline $\mathrm{t} 1.58$ & Trachyte & Palizzi lava & Ti-mt & sc1824 11-12 & 1 & $\mathrm{~b}$ & 31.37 & 29.73 & bdl & bdl & bdl & bdl & 38.91 & 100.00 \\
\hline $\mathrm{t} 1.59$ & Trachyte & Palizzi lava & cpx & sc1824 4-5-6 & 1 & b & 20.42 & 28.20 & bdl & bdl & bdl & bdl & 51.38 & 100.00 \\
\hline $\mathrm{t} 1.60$ & Trachyte & Palizzi lava & $\mathrm{cpx}$ & sc1824 4-5-6 & 1 & $\mathrm{~b}$ & 2.27 & 18.68 & bdl & bdl & bdl & bdl & 79.05 & 100.00 \\
\hline $\mathrm{t} 1.61$ & Trachyte & Palizzi lava & $\mathrm{cpx}$ & reconstructed *sc1824 4-5-6 & 1 & b & 10.89 & 23.21 & bdl & bdl & bdl & bdl & 65.90 & 100.00 \\
\hline $\mathrm{t} 1.62$ & Trachyte & Palizzi lava & $\operatorname{cpx}$ & sc1824 7-8 & 1 & $\mathrm{~b}$ & 29.89 & 29.63 & bdl & bdl & bdl & bdl & 40.48 & 100.00 \\
\hline $\mathrm{t} 1.63$ & Trachyte & Palizzi lava & cpx & sc1824 7-8 & 1 & b & 22.97 & 28.30 & bdl & bdl & bdl & bdl & 48.73 & 100.00 \\
\hline $\mathrm{t} 1.64$ & Trachyte & Palizzi lava & cpx & reconstructed *sc1824 7-8 & 1 & b & 25.18 & 28.73 & bdl & bdl & bdl & bdl & 46.09 & 100.00 \\
\hline $\mathrm{t} 1.65$ & Latite & Pal C & Ti-mt & sulf n4 & 1 & b & 28.65 & 32.34 & bdl & bdl & bdl & bdl & 39.01 & 100.00 \\
\hline $\mathrm{t} 1.66$ & Latite & Pal C & Ti-mt & solf n4 & 1 & b & 11.75 & 25.37 & bdl & bdl & bdl & bdl & 62.88 & 100.00 \\
\hline $\mathrm{t} 1.67$ & Latite & Pal C & Ti-mt & reconstructed *solfn 4 & 1 & b & 18.51 & 28.15 & bdl & bdl & bdl & bdl & 53.34 & 100.00 \\
\hline $\mathrm{t} 1.68$ & Rhyolite & Pal B & sa & pallentiasulf1 & 2 & $\mathrm{a}$ & 59.58 & 36.72 & 0.03 & 0.03 & 0.04 & 0.09 & 0.33 & 96.81 \\
\hline $\mathrm{t} 1.69$ & Rhyolite & Pal B & sa & pallentiasulf1 & 2 & $\mathrm{a}$ & 58.57 & 36.56 & 0.04 & 0.07 & 0.01 & bdl & 0.42 & 95.67 \\
\hline
\end{tabular}

some intermediate composition MIs. Conversely, Pb concentration in MIs increases from basalt ( $5 \mathrm{ppm})$ to trachyte $(35 \mathrm{ppm})$ and remains constant in rhyolites (Fig. 3b).

The average metal concentrations measured in Type 2 SIs (Table 2) and in coexistent MIs (Table 4) allow the sulfide phase/ silicate melt partition coefficients for $\mathrm{Cu}(1184)$, Ni (352), $\mathrm{Zn}$
(1.25), V (3.17), $\mathrm{Pb}(1.77)$ to be calculated. The sulfide phase/silicate melt partition coefficients for the same metals in Type 1 sulfides, mostly lacking coexistent melt inclusions, are determined assuming the average $\mathrm{Cu}$ content of latitic-trachytic melt inclusions (Table 4) and are 1538 for $\mathrm{Cu}, 154$ for Ni, 1.32 for $\mathrm{Zn}, 1.8$ for $\mathrm{V}$ and 76 for $\mathrm{Pb}$. 


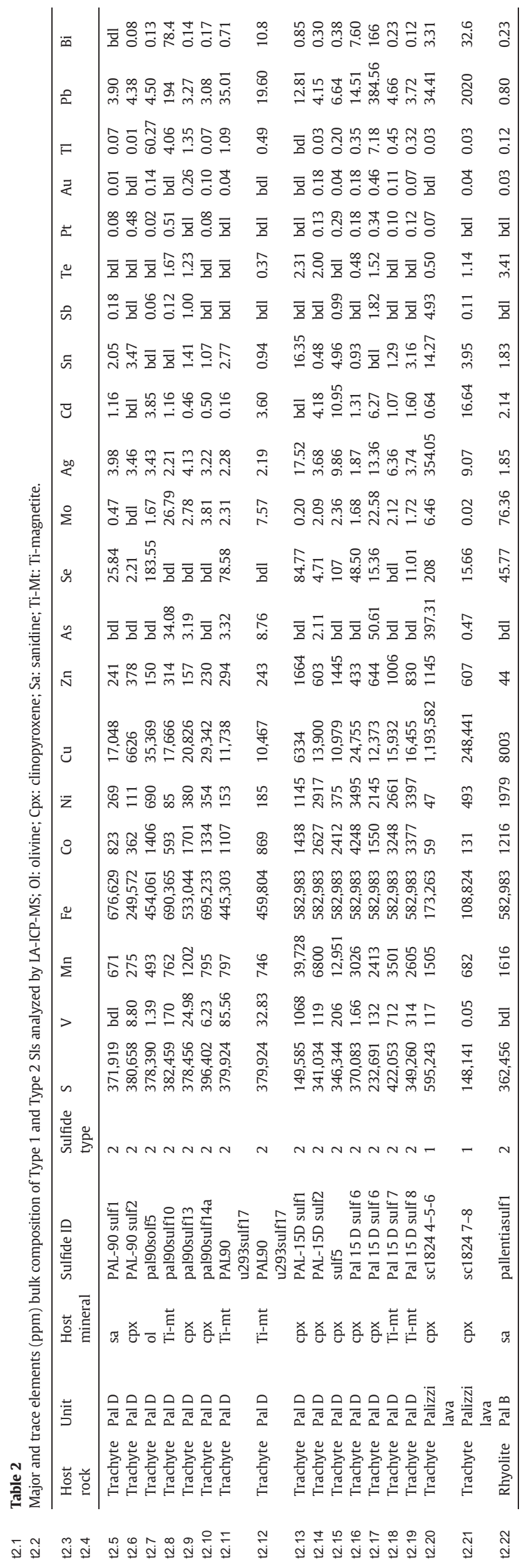

\section{Discussion}

\subsection{Evolution of metals in the magmas}

The petrographic features and the chemical compositions of MIs and SIs found in Vulcano eruptive products allow the evolution of metals in the magmatic system of an active arc volcano to be tracked from basalt to rhyolite. This system is fed by sulfide-undersaturated, $\mathrm{H}_{2} \mathrm{O}$-rich and oxidized basaltic magmas. The first appearance of SIs indicates that sulfide saturation occurs late, during magma evolution, at the latitetrachyte transition. Accordingly, the $\mathrm{fO}_{2}$ value decreases from basalts $(\mathrm{NNO}-\mathrm{NNO}+1)$ to intermediate magmas (trachyte magma $\triangle \mathrm{NNO}-1$ to -2 ; Fulignati et al., 2018). This is potentially due to the combined effects of lower temperatures, the fractionation of Fe-bearing minerals and the volatile loss during differentiation (Richards, 2015; Scaillet and MacDonald, 2006; Scaillet and Pichavant, 2005). At Vulcano island, sulfide saturation is unrelated to the sudden onset of magnetite crystallization ("magnetite crisis", Jenner et al., 2010), because magnetite fractionation starts early, while sulfide saturation is late.

Magmatic sulfide inclusions could be trapped either as a liquid (SL) or as a solid, which can be either a monosulfide solid solution (mss) or an intermediate solid solution (iss), having a composition close to pyrrhotite and chalcopyrite, respectively (Parat et al., 2011). For most metals, the partition coefficient between sulfide and silicate melt strongly depends on the nature of the sulfide phase ( $m s s$, iss, or SL; Li and Audétat, 2015). Thus, determining the nature of the sulfide phases at the time of trapping is important to constrain the metal budget of the magmatic system (Rottier et al., 2019 and references therein). By plotting both Type 1 and Type 2 SIs analyses on the ternary diagram of the Cu-Fe-S system (at $1000{ }^{\circ} \mathrm{C}$ ), the reconstructed Type 1 SIs compositions fall in the liquid field, whereas Type 2 SIs fall in the pyrrothite ( $m s s$ ) field, suggesting that the latter were trapped as a solid phase. This evidence is supported by comparing their sulfide phase-silicate melt partition coefficients (for $\mathrm{Cu}, \mathrm{Ni}, \mathrm{Pb}, \mathrm{Zn}$ ), calculated from measured concentrationsandpredictedaccordingtotheequationsforD ${ }_{S \mathrm{~L} / \mathrm{SM}}^{\mathrm{X}}$, $\mathrm{D}_{\mathrm{mss} / \mathrm{SM}}^{\mathrm{X}}$ of Li and Audétat (2015) for a trachyte melt with $950{ }^{\circ} \mathrm{C}, \Delta \mathrm{FMQ}$ -0.77 and $\mathrm{FeO} 4.4$ wt\%. The comparison shown in Fig. 4 demonstrates a good match for both the Type 1 and the Type 2 SIs (these elements were selected because they could be reliably quantified in both magmatic sulfide and silicate melt inclusions, and because their partition coefficient is markedly different for mss versus SL). The different partition coefficients SL/SM and mss/SM are also in agreement with the measured $\mathrm{Ag}$ and $\mathrm{Pb}$ contents, which are considerably higher in Type 1 SIs than in Type 2 SIs.

The $\mathrm{Cu}$ behavior in the silicate melt confirms late sulfide saturation (Fig. 3a). In fact, $\mathrm{Cu}$ concentration in MIs increases from basalt to latite melts, which are sulfide-undersaturated, and then rapidly decreases within a narrow compositional interval ( $\mathrm{Zr} 180-200$ ppm; $\mathrm{SiO}_{2}$ 58-60 wt\%) once sulfide saturation is reached, due to the stripping of $\mathrm{Cu}$ by $\mathrm{Cu}$-rich sulfide melt. The scattered $\mathrm{Cu}$ concentrations, including very low values in the intermediate composition MIs range, might suggest that: (i) incipient sulfide saturation was achieved in some parts of the reservoir (at the contact with wall rock thanks to temperature decrease, fractional crystallization or silica assimilation?) although not revealed by sulfide trapping; (ii) Cu was episodically lost to a S-rich vapor phase from mafic magmas. Events of refilling by $\mathrm{Cu}$-poor, S-rich and sulfide undersaturated magma could furthermore enhance the heterogeneity in the $\mathrm{Cu}$ content of an intermediate composition reservoir. This is particularly crucial because, in order to represent the entire basalt to rhyolite differentiation range, we analyzed samples that do not necessarily represent the evolution in a single reservoir but rather come from multiple, possibly independent magma batches with variable age.

The evolution of $\mathrm{Cu}$ and $\mathrm{Pb}$ in the silicate melt has been modeled with fractional crystallization, starting from a mean value of the La Sommata basaltic MIs and including a sulfide phase in the fractionating assemblage at the latite-trachyte stage (Fig. 3a, b). For this study, we 
neglected crustal assimilation processes. The model employs bulk distribution coefficient for $\mathrm{Zr}$, $\mathrm{Cu}$ and $\mathrm{Pb}$, calculated for each step of the differentiation process using partition coefficients derived from the literature and the relative proportions of crystallizing phases for Vulcano (Costa et al., 2020; see Supplementary Material S1 for details of the model). The sulfide phase/silicate melt partition coefficients for $\mathrm{Pb}$ and $\mathrm{Cu}$ were calculated according to Li and Audétat (2015) (Supplementary Material S1).

The models provide a robust explanation of the $\mathrm{Cu}$ behavior in the silicate melt. The fractional crystallization models predict that $0.2-0.3 \mathrm{wt} \%$ of sulfide melt fractionated along with clinopyroxene +

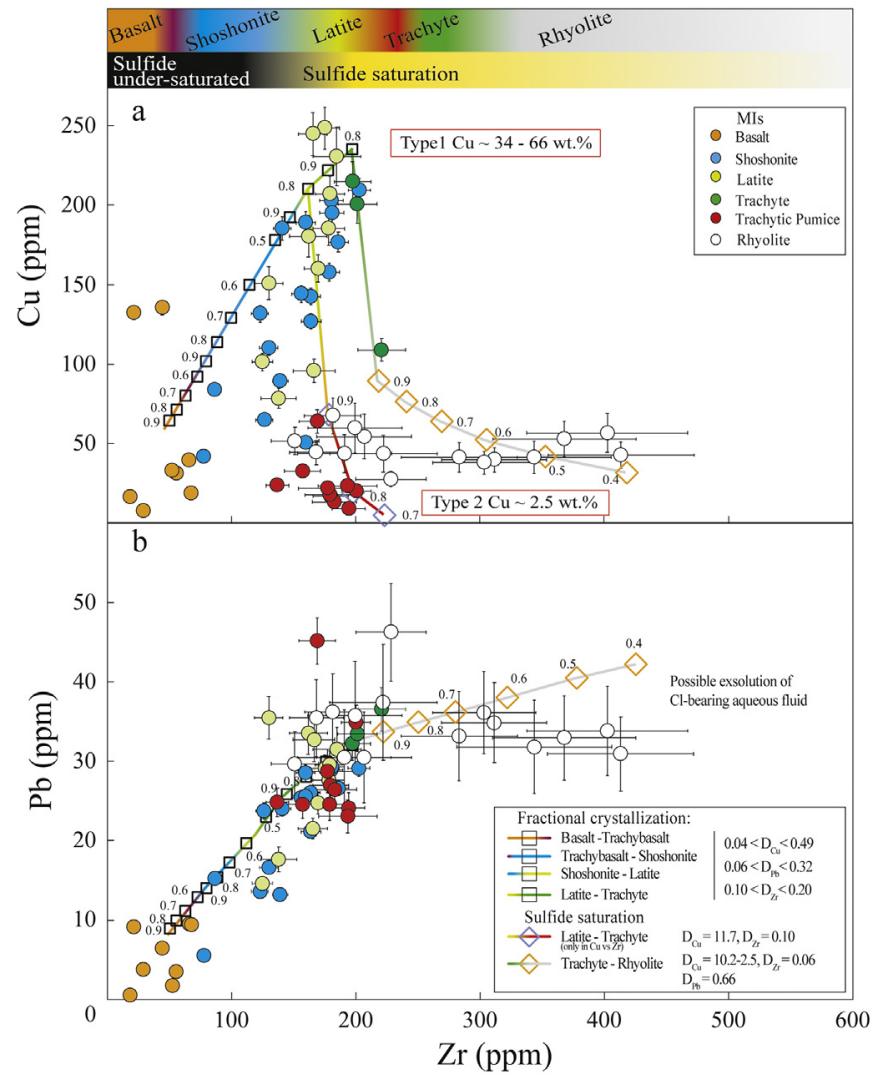

Fig. 3. Copper (a) and $\mathrm{Pb}$ (b) versus $\mathrm{Zr}$ as differentiation index for the glassy MIs representative of the basalt to rhyolite suite at Vulcano, with quantitative fractional crystallization model for the evolution of $\mathrm{Cu}$ and $\mathrm{Pb}$ in the silicate melt. Bulk partition coefficients (D) for $\mathrm{Cu}, \mathrm{Pb}$ and $\mathrm{Zr}$ have been calculated using minerals/silicate melt partition coefficients from literature and sulfide/silicate melt partition coefficients calculated with the model of Li and Audétat (2015). See supplementary material S1 for additional details. 1 sigma error for each analysis is shown as error bars, which if not visible, is smaller than the symbol. Symbols and numbers along the fractionation paths indicate melt fraction. plagioclase + Ti-magnetite + olivine + biotite + sanidine. This is sufficient to cause a sharp drop in the $\mathrm{Cu}$ content of silicate melt at the latite to trachyte transition. Because Type 1 and Type 2 SIs were never found to coexist, we suggest that the first sulfides formed at the highest $\mathrm{Cu}$ content are correspondingly Cu-rich (Type 1 SIs), whereas those exsolved from the Cu-depleted trachytic magma are the Cu-poor Type 2 SIs (Cu-bearing mss) found in trachyte and rhyolite (Fig. 3a). This reconstruction is in agreement with the composition of clinopyroxene crystals in the latites and trachytes. Clinopyroxene composition testifies that, in the latite-to-trachyte transition, the Cu-depleted trachytic magma is slightly more evolved (that is, having a lower $\mathrm{Cr}, \mathrm{V}$ and $\mathrm{Ni}$ content in clinopyroxenes) than the $\mathrm{Cu}$-rich trachyte and latite (Fig. 5). The trachyte-rhyolite step requires a high percentage (60 vol\%) of fractionated solid (Costa et al., 2020), strongly increasing the final concentration of incompatible elements and possibly explaining the large spread in $\mathrm{Zr}$ values measured in rhyolites.

The evolution of $\mathrm{Pb}$ shows an increase with differentiation up to rhyolite (Fig. 3b). This agrees well with the low sulfide melt/silicate melt partition coefficient for this element, which is orders of magnitude lower than that of $\mathrm{Cu}$ (this work and Li and Audétat, 2015). The modeled $\mathrm{Pb}$ trend in rhyolites $(\mathrm{Zr}>200 \mathrm{ppm})$, despite the higher $\mathrm{D}_{\mathrm{Pb}}$, slightly deviates from the measured data. This may be ascribed to the partitioning of $\mathrm{Pb}$ in an exsolved $\mathrm{Cl}$-bearing aqueous fluid.

\subsection{The effect of fluid saturation}

Tracking metal evolution in magmas cannot overlook the effect of fluid-saturation along differentiation. While Vulcano basalts are $\mathrm{H}_{2} \mathrm{O}$-, $\mathrm{S}-, \mathrm{Cl}$-rich, the shoshonitic magmas have lower volatile contents (Gioncada et al., 1998), suggesting that $\mathrm{H}_{2} \mathrm{O}, \mathrm{S}$ and $\mathrm{Cl}$ may be lost to an exsolved aqueous fluid phase at the basalt-shoshonite transition. Our results show that, despite mafic magmas degassing during ascent, $\mathrm{Cu}$ and $\mathrm{Pb}$ increase with differentiation (Fig. 3a, b). This suggests that the evolution of these metals is not significantly affected by decompression degassing of mafic magmas as they refill crustal reservoirs. Indeed, $\mathrm{Cu}$ scarcely partitions into a hydrosaline fluid phase exsolved from mafic magmas according to the experimental results of Zajacz et al. (2012).

In trachytes and rhyolites, the Cu-normalized abundances of S, Mo, $\mathrm{Zn}, \mathrm{Ag}, \mathrm{Pt}, \mathrm{Au}, \mathrm{Pb}$ in Type 1 (trachyte) and Type 2 (trachyte and rhyolite) SIs show different patterns (Fig. 6). While Mo/Cu ratio in the rhyolite Type 2 SIs is higher than that of Type 2 SIs in trachyte, $\mathrm{Zn} / \mathrm{Cu}$ and $\mathrm{Pb} /$ $\mathrm{Cu}$ are distinctly lower (Fig. 6a). This is in agreement with the exsolution of a Cl-rich magmatic fluid phase from the rhyolitic magma at La Fossa (Fulignati et al., 2018), causing Pb and Zn to preferentially partition with respect to Mo (Zajacz et al., 2008). Mo, which is not efficiently partitioned in a Cl-rich magmatic fluid phase (Candela and Holland, 1984; Zajacz et al., 2008), tends to also increase in the rhyolite SIs.

At Vulcano, previous data suggest that metal-bearing fluids can be involved in phreatic-phreatomagmatic eruptions (Gurioli et al., 2012). An example is the Breccia di Commenda eruption, a violent explosive 


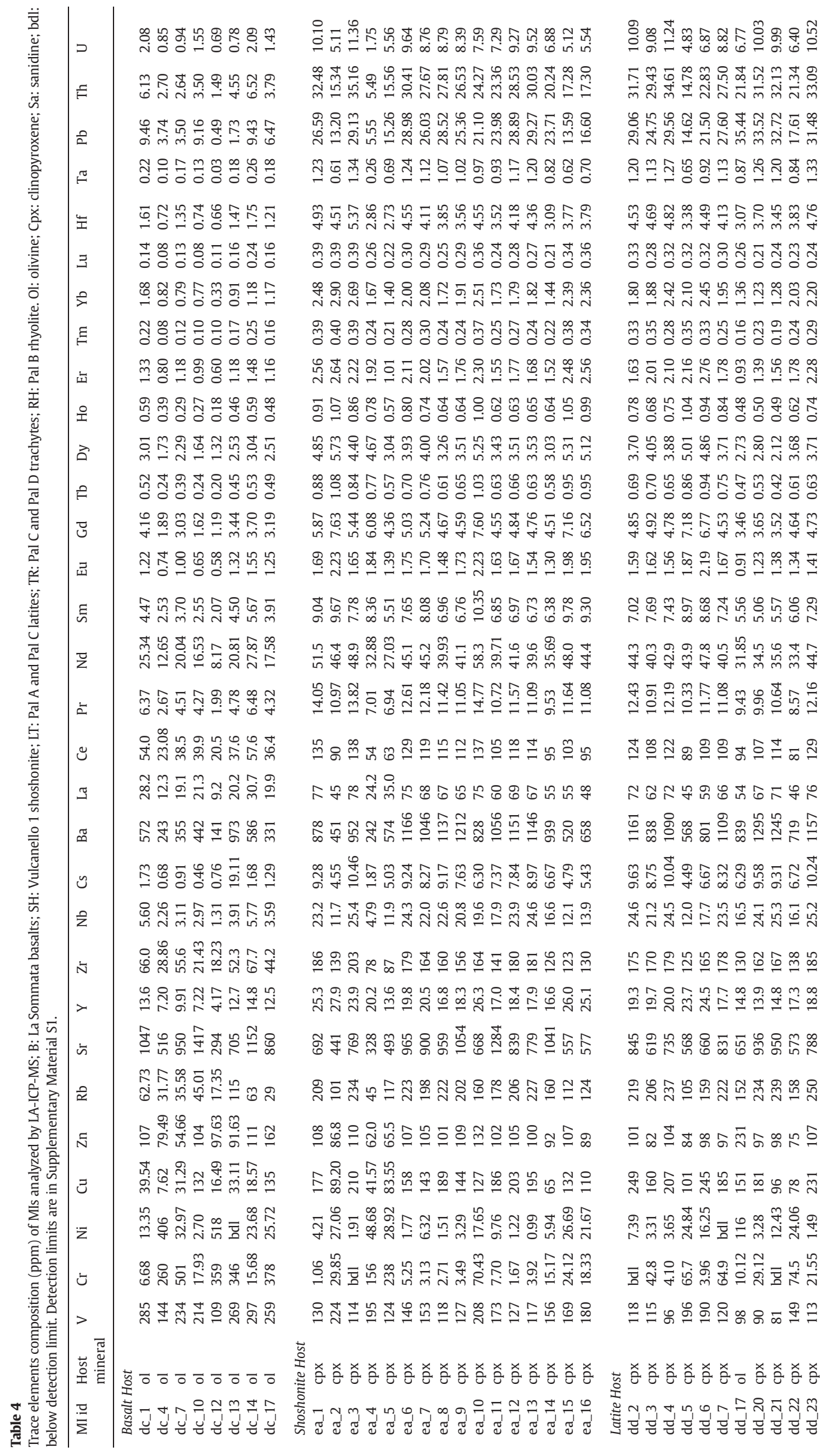

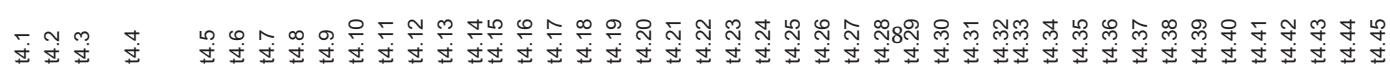




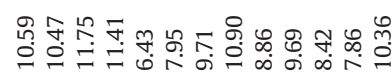

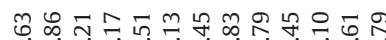

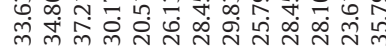

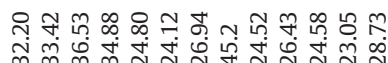

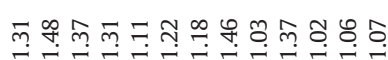

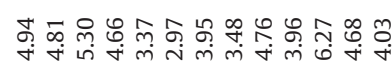

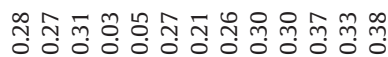

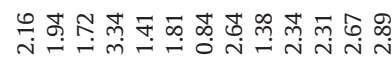

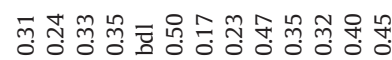

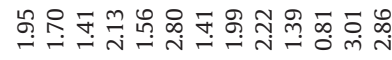

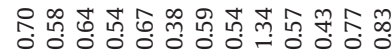

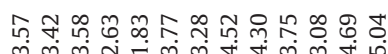

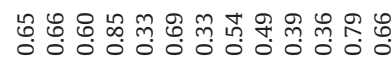

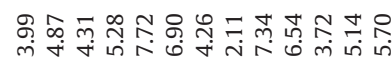

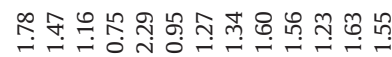

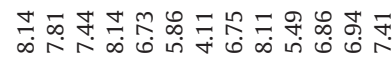

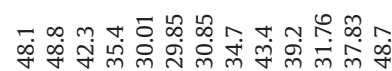

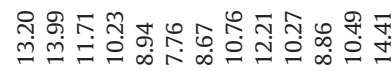

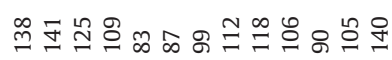

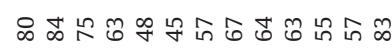

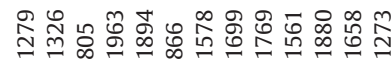

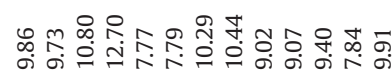

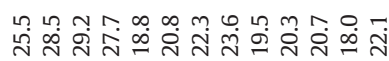

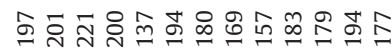

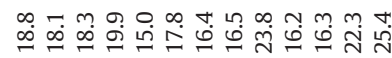

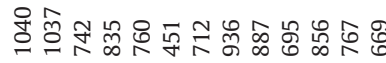

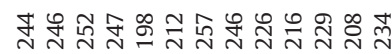

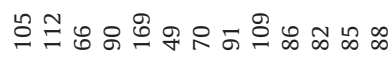

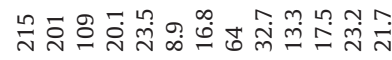

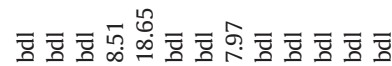

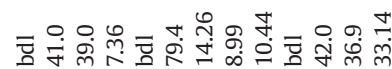

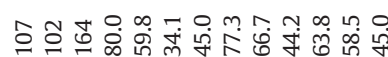

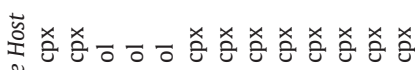

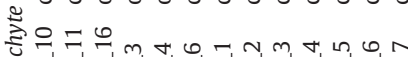

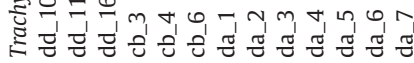

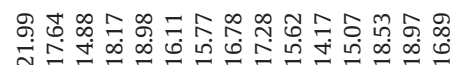

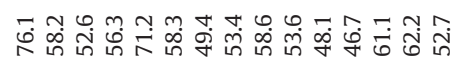

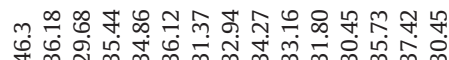

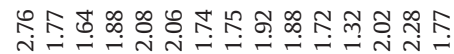

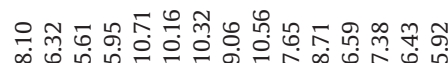

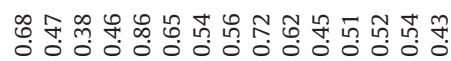

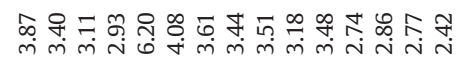

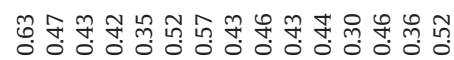

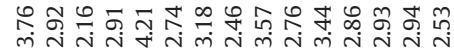

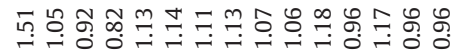

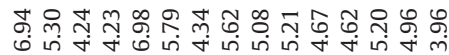

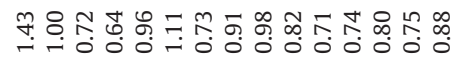

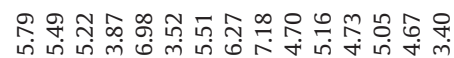

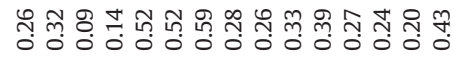

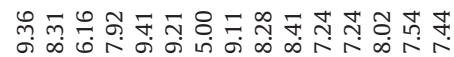

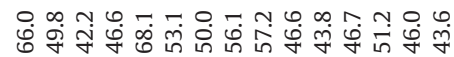

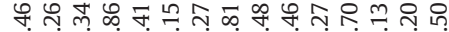

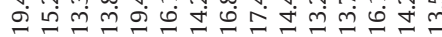

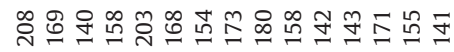

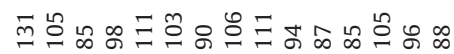

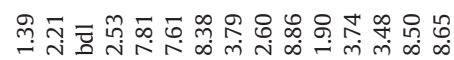

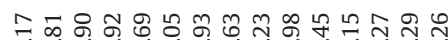

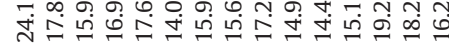

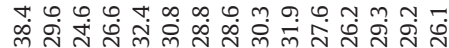

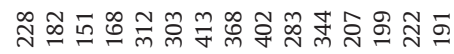

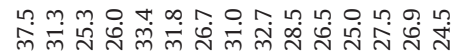

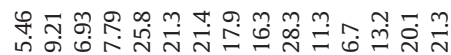

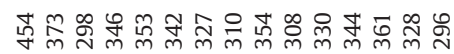

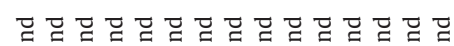

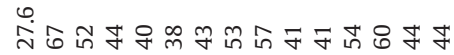
홍 ‡

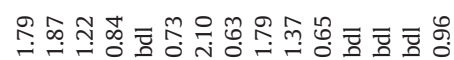

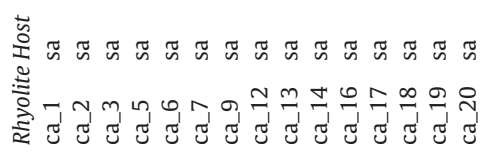



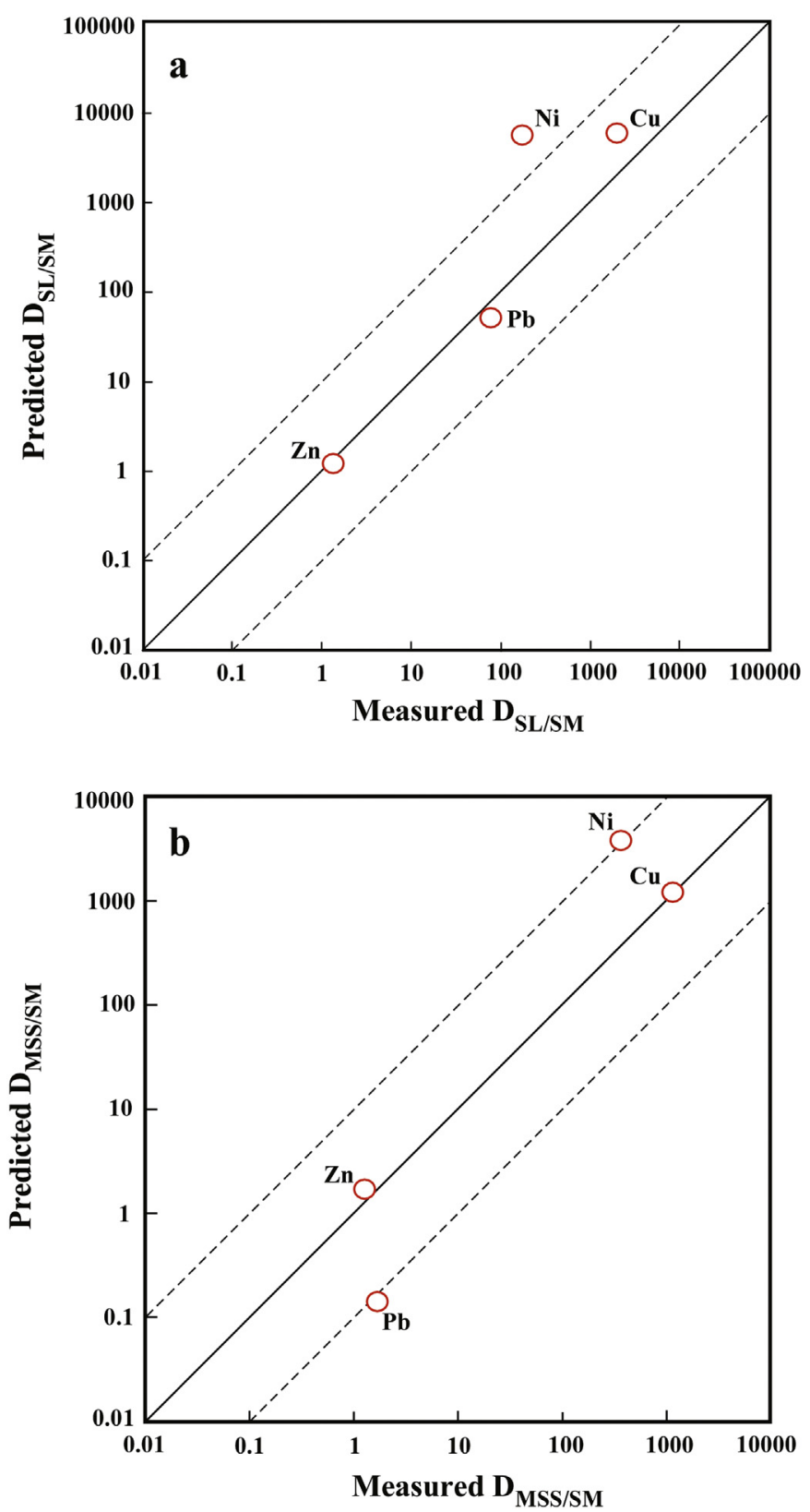

Fig. 4. Comparison of measured sulfide - silicate melt partition coefficients with values predicted by the model of Li and Audétat (2015); (a) sulfide liquid (Type 1 SIs)-silicate melt (b) monosulfide solid solution (Type 2 SIs)-silicate melt. T of $950{ }^{\circ} \mathrm{C}, \Delta \mathrm{FMQ}=-$ 0.77 and $\mathrm{FeO}$ in the melt $=4.4 \mathrm{wt} \%$ estimated for La Fossa trachyte by Fulignati et al. (2018) have been used in the model.

event occurred at La Fossa volcano during XIII Cent. AD. This eruption produced a high amount of lithics which showed acid-sulfate alteration (Gurioli et al., 2012). Interestingly, $\mathrm{S} / \mathrm{Cu}, \mathrm{Zn} / \mathrm{Cu}, \mathrm{Pb} / \mathrm{Cu}$ ratios measured on the fine ash of the Breccia di Commenda deposits are higher than the same ratios measured in the trachytic and rhyolitic SIs (Fig. 6a). This suggests that $\mathrm{Cl}$-rich fluids carrying $\mathrm{Pb}$ and $\mathrm{Zn}$ from the magmatic-hydrothermal system were involved in the Breccia di Commenda eruption.

\subsection{Comparison with mineralized systems}

With the aim to compare the SIs composition in the products of an active arc volcano with that of SIs from magmas associated with porphyry mineralization, absolute and Cu-normalized metal
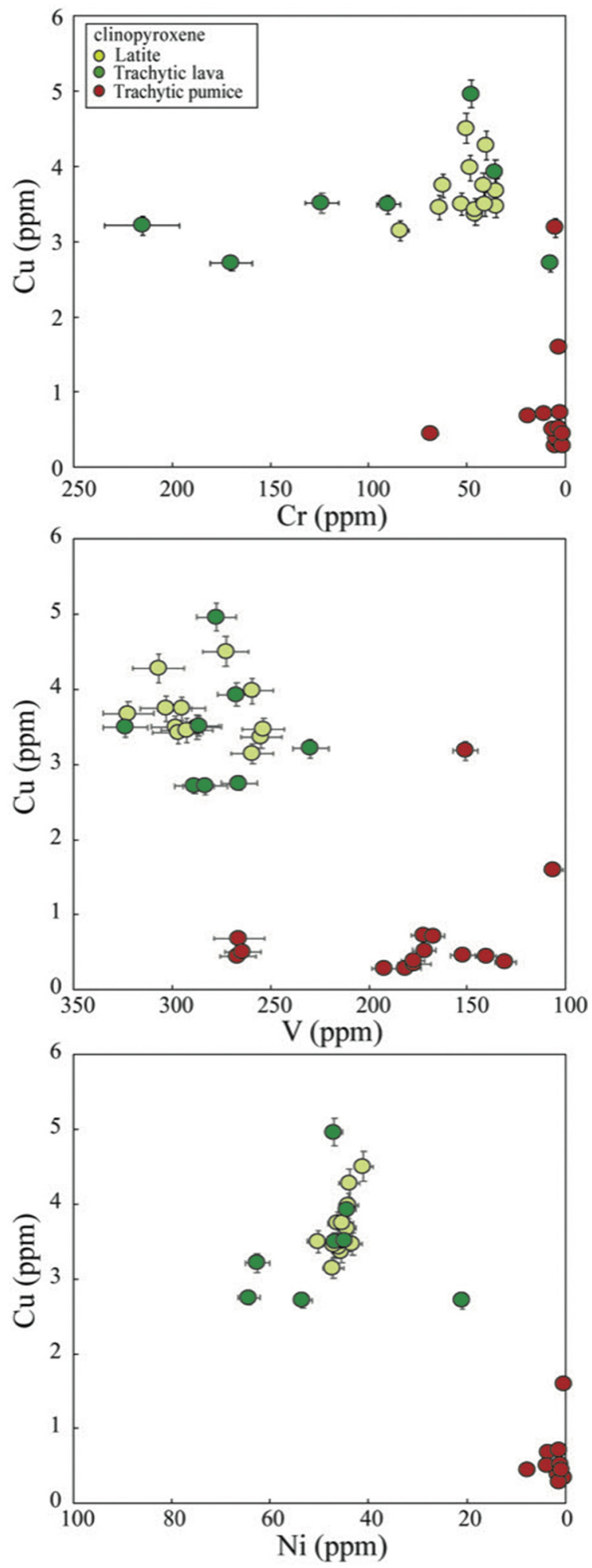

Fig. 5. Cu versus $\mathrm{Cr}, \mathrm{V}$ and $\mathrm{Ni}$ content for clinopyroxene crystals in the latitic and trachytic products of La Fossa hosting the type 1 (yellow and green symbols) and type 2 (red symbols) SIs. See the supplementary material S1 for the complete data set of analyses of clinopyroxene. 1 sigma error for each analysis is shown as error bars, which if not visible, is smaller than the symbol. (For interpretation of the references to colour in this figure legend, the reader is referred to the web version of this article.)

concentrations from La Fossa are compared with those found in well-preserved SIs of ore-related igneous rocks. The metal ratios and absolute concentrations in Vulcano SIs (either in Type 1 and Type 2 

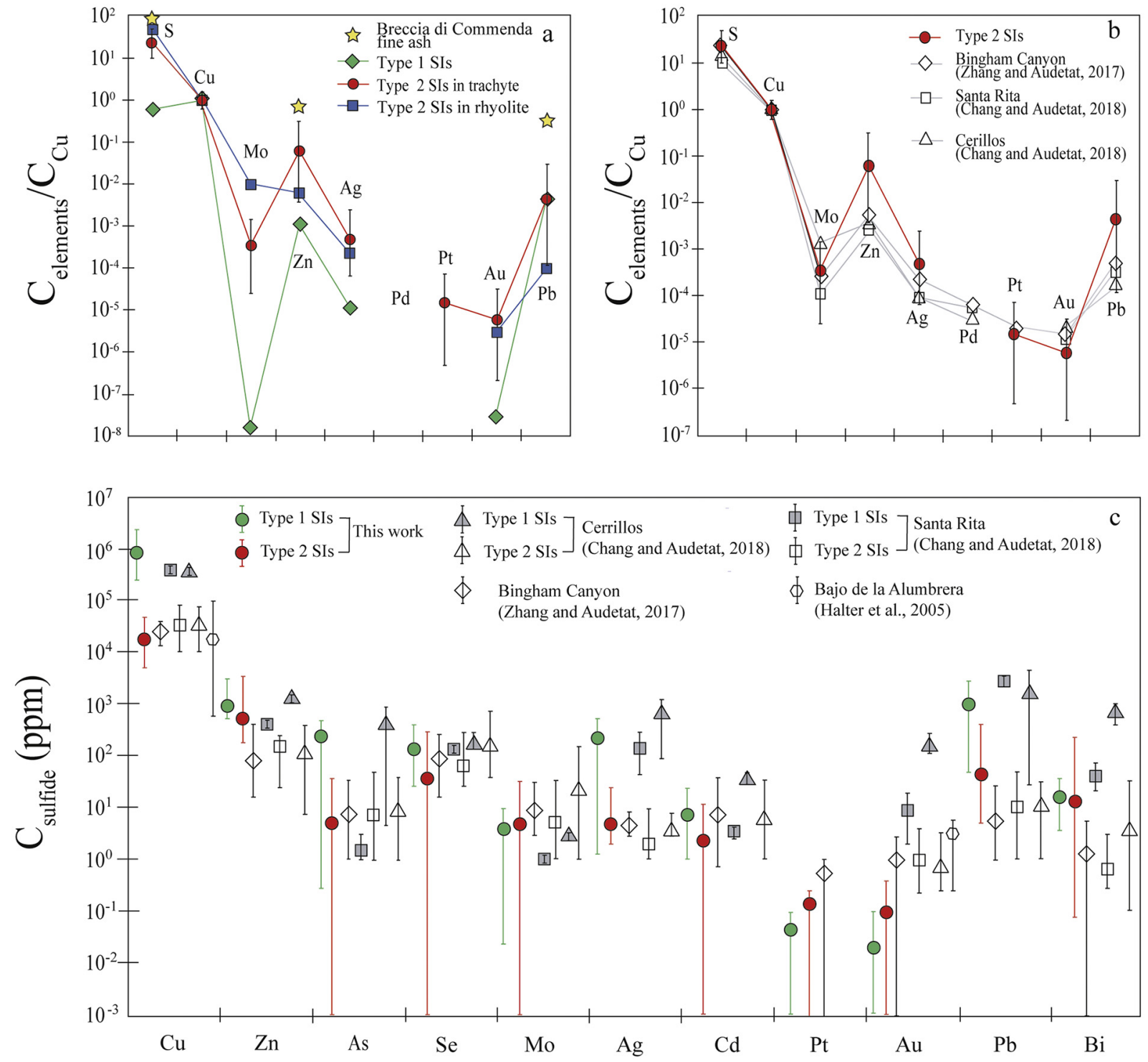

Fig. 6. (a) Cu-normalized composition of La Fossa SIs and Breccia di Commenda fine ash; (b) Cu-normalized composition (average and range) of Type 2 SIs compared to SIs of ore-related latitic magma at Bingham and at Santa Rita and Cerrillos; (c) Absolute metal concentrations in Type 1 and Type 2 La Fossa SIs compared with those found in mineralized systems (Bingham Canyon, Santa Rita, Cerrillos and Bajo de la Alumbrera).

SIs) match well with those of mineralized systems (Fig. 6b, c). This suggests that, at Vulcano, the late attainment of sulfide saturation during fractionation in mid-upper crustal reservoirs prevents the early depletion in $\mathrm{S}$ and chalcophile metals and produces magmatic sulfide melts with compositions comparable to those found in several porphyry systems. Once formed, the sulfides may be stored in crystal mushes of intermediate to evolved crustal reservoirs, re-melted by mafic sulfide-undersaturated recharges or eventually cannibalized by aqueous fluids exsolving at the rhyolite stage, thereby producing highly mineralizing solutions (Audétat and Simon, 2012; Halter et al., 2002; Keith et al., 1997; Nadeau et al., 2010; Wilkinson, 2013).

Our results indicate that the processes governing metal evolution through silicate melt differentiation in active arc magmatic systems share similarities to those inferred for magmas associated to porphyry Cu systems. Bearing in mind that the magmatic stage is arguably pivotal in the evolution of porphyry Cu systems (Audétat and Simon, 2012), arc volcanoes such as La Fossa can thus be viewed as active analogues and ideal sites for studying the critical early stages of porphyry Cu genesis. Their possibility to evolve toward mineralized systems will, of course, depend also on other factors (magma chamber size and depth, duration of magmatic and hydrothermal activity, and the efficiency of magmatic fluid focusing; Richards, 2011; Wilkinson, 2013) that can either promote or inhibit porphyry Cu formation.

\section{Conclusive remarks}

In this work, we used combined compositional data (major, minor and trace element) on melt inclusions, magmatic sulfides and host minerals from the eruptive products of the arc volcano of La Fossa (Vulcano Island, Italy), to track the evolution of metals along the magma differentiation path of an active magmatic system. We found that, in case of sulfide-undersaturated, volatile-rich arc basalts, metals are scarcely subtracted by degassing during ascent to shallow crustal reservoirs and thus reach their highest abundances in intermediate magmas. Further evolution results in sulfide saturation where $\mathrm{Cu}$ and chalcophile metals strongly partition into the sulfide melt, causing a dramatic decrease in abundance from the silicate melt. The evolution of $\mathrm{Cu}$ in the silicate melts was modeled with quantitative fractional crystallization, and 
the results are in close agreement with experimental data. The model shows that fractionation of only $0.2-0.3 \mathrm{wt} \%$ of sulfide is sufficient to deplete the silicate melt in Cu down to the values recorded by MIs in trachytic and rhyolitic products. Metals that do not partition in sulfides $(\mathrm{Pb}, \mathrm{Zn})$ increase their concentrations with magmatic evolution until they are scavenged by a Cl-rich aqueous fluid phase, possibly exsolved at the rhyolitic stage.

The comparison of metal ratios and absolute concentrations of the Vulcano magmatic sulfides with those of sulfides found in magmatic rocks, associated with world-class porphyry $\mathrm{Cu}$ systems, shows strong similarities. This suggests that the processes governing metal evolution through silicate melt differentiation in active arc magmatic systems are similar to those processes inferred for magmatic stage of porphyry $\mathrm{Cu}$ environments. Our results thus suggest that the investigation of metal evolution in active arc volcanoes such as La Fossa can provide information for interpreting the genetic mechanisms of porphyry Cu deposit formation.

\section{Declaration of Competing Interest}

The authors declare that they have no known competing financial interests or personal relationships that could have appeared to influence the work reported in this paper.

\section{Acknowledgements}

We warmly thank Prof. Jung-Woo Park for the review of an early version of the manuscript. We would also like to thank Greg Shellnutt for editorial handling. The present manuscript benefited from the constructive review of two anonymous referees whose comments and suggestions helped to improve the quality and clarity of the manuscript. The authors thank R. Ishak (Università di Pisa), A. Risplendente (Università di Milano), for assistance during analytical work, F. Colarieti and M. Gemelli (Università di Pisa) for sample preparation and M. D. Suttle for helping us with English editing. This research was funded by projects PRA_2018_41 to PF and MP and FFABR2017 to AG. This research is part of SC PhD program funded by a Tuscany Regional "Pegaso" doctoral grant.

\section{Appendix A. Supplementary data}

\section{References}

Audétat, A., Simon, A.C., 2012. Magmatic controls on porphyry copper genesis. In: Hedenquist, J.W., et al. (Eds.), Geology and Genesis of Major Copper Deposits and Districts of the World: A Tribute to Richard H. Sillitoe. 16. Society of Economic Geologists Special Publications, pp. 1-18.

Bai, Z.-J., Zhong, H., Hu, R.-Z., Zhu, W.-G., 2020. Early sulfide saturation in arc volcanic rocks of Southeast China: Implications for the formation of co-magmatic porphyryepithermal Cu-Au deposits. Geochim. Cosmochim. Acta 280, 66-84.

Boyce, A.J., Fulignati, P., Sbrana, A., Fallick, A.E., 2007. Fluids in early stage hydrothermal alteration of high-sulfidation epithermal systems: a view from the Vulcano active hydrothermal system (Aeolian Island, Italy). J. Volcanol. Geotherm. Res. 166, 76-90.

Candela, P.A., Holland, H.D., 1984. The partitioning of copper and molybdenum between silicate melts and aqueous fluids. Geochim. Cosmochim. Acta 48, 373-380.

Chang, J., Audétat, A., 2018. Petrogenesis and metal content of Horneblende-rich Xenoliths from two Laramide-age Magma systems in Southwestern USA: insights into the Metal Budget of Arc Magmas. J. Petrol. 59, 1869-1898.

Chen, K., Tang, M., Lee, C.-T.A., Wang, Z., Zou, Z., Hu, Z., Liu, Y., 2020. Sulfide-bearing cumulates in deep continental arcs: the missing copper reservoir. Earth Planet. Sci. Lett. 531, 115971. https://doi.org/10.1016/j.epsl.2019.115971.

Costa, S., Masotta, M., Gioncada, A., Pistolesi, M., Bosch, D., Scarlato, P., 2020. Magma evolution at La Fossa volcano (Vulcano Island, Italy) in the last 1000 years: evidence from eruptive products and temperature gradient experiments. Contrib. Mineral. Petrol. $175,31$.

Cox, D., Watt, S.F.L., Jenner, F.E., Hastie, A.R., Hammond, S.J., 2019. Chalcophile element processing beneath a continental arc stratovolcano. Earth Planet. Sci. Lett. 522, 1-11.
Craig, J.R., Kullerud, G., 1969. Phase relations in the Cu-Fe-Ni-S system and their application to magmatic ore deposits. Econ. Geol. Monogr. 4, 344-358.

De Astis, G., Peccerillo, A., Kempton, P.D., La Volpe, L., Wu, T.W., 2000. Transition from calc-alkaline to potassium-rich magmatism in subduction environments: geochemical and Sr, Nd, Pbisotopic constraints from the island of Vulcano (Aeolian arc). Contrib. Mineral. Petrol. 139, 684-703.

De Astis, G., Lucchi, F., Dellino, P., La Volpe, L., Tranne, C.A., Frezzotti, M.L., Peccerillo, A., 2013. Geology volcanic history and petrology of Vulcano (central Aeolian archipelago). Geol. Soc. Lond. Mem. 37, 281-349.

Fulignati, P., Gioncada, A., Sbrana, A., 1998. Geologic model of the magmatichydrothermal system of Vulcano (Aeolian Island, Italy). Mineral. Petrol. 62, 195-222.

Di Traglia, F., Pistolesi, M., Rosi, M., Bonadonna, C., Fusillo, R., Roverato, M., 2013. Growth and erosion: The volcanic geology and morphological evolution of La Fossa (Island of Vulcano, Southern Italy) in the last 1000 years. Geomorphology 194, 94-107. https:// doi.org/10.1016/j.geomorph.2013.04.018.

Fulignati, P., Gioncada, A., Costa, S., Di Genova, D., Di Traglia, F., Pistolesi, M., 2018. Magmatic sulfide immiscibility at an active magmatic-hydrothermal system: the case of la Fossa (Vulcano, Italy). J. Volcanol. Geotherm. Res. 358, 45-57.

Fusillo, R., Di Traglia, F., Gioncada, A., Pistolesi, M., Wallace, P.J., Rosi, M., 2015. Deciphering post-caldera volcanism: insight into the Vulcanello (Island of Vulcano, Southern Italy) eruptive activity based on geological and petrological constraints. Bull. Volcanol. 77, 76.

Georgatou, A., Chiaradia, M., 2020. Magmatic sulfides in high-potassium calc-alkaline to shoshonitic and alkaline rocks. Solid Earth 11,1-21.

Georgatou, A., Chiaradia, M., Rezeau, H., Walle, M., 2018. Magmatic sulphides in Quaternary Ecuadorian arc magmas. Lithos 296-299, 580-599.

Gioncada, A., Clocchiatti, R., Sbrana, A., Bottazzi, P., Massare, D., Ottolini, L., 1998. A study of melt inclusions at Vulcano (Aeolian Islands, Italy): insights on the primitive magmas and on the volcanic feeding system. Bull. Volcanol. 60, 286-306.

Gurioli, L., Zanella, E., Gioncada, A., Sbrana, A., 2012. The historic magmatic-hydrothermal eruption of the Breccia di Commenda, Vulcano, Italy. Bull. Volcanol. 74, 1235-1254.

Halter, W.E., Pettke, T., Heinrich, C.A., 2002. The origin of Cu/au ratios in porphyry-type ore deposits. Science 296, 1844-1846.

Halter, W.E., Heinrich, C.A., Pettke, T., 2005. Magma evolution and the formation of porphyry Cu-Au ore fluids: evidence from silicate and sulfide melt inclusions. Mineral. Deposita 39, 845-863.

Hao, H., Campbell, I.H., Richards, J.P., Nakamura, E., Sakaguchi, C., 2019. Platinum-group element geochemistry of the Escondida Igneous suites, Northern Chile: Implications for ore formation. J. Petrol. 60, 487-524.

Hedenquist, J.W., Lowenstern, J.B., 1994. The role of magmas in the formation of hydrothermal ore-deposits. Nature 370, 519-527.

Jenner, F.E., O'Neill, H.S.C., Arculus, R.J., Mavrogenes, J.A., 2010. The magnetite crisis in the evolution of arc-related magmas and the initial concentration of $\mathrm{Au}, \mathrm{Ag}$ and $\mathrm{Cu}$. J. Petrol. 51, 2445-2464.

Keith, J.D., Whitney, J.A., Hattori, K., Ballantyne, G.H., Christiansen, E.H., Barr, D.L., Cannan, T.M., Hook, C.J., 1997. The role of magmatic sulfides and mafic alkaline magmas in the Bingham and Tintic mining districts, Utah. J. Petrol. 38, 1679-1690.

Le Voyer, M., Asimow, P.D., Mosenfelder, J.L., Guan, Y., Wallace, P.J., Schiano, P., Stolper, E.M., Eiler, J.M., 2014. Zonation of $\mathrm{H}_{2} \mathrm{O}$ and $\mathrm{F}$ concentrations around melt inclusions in olivines. J. Petrol. 55, 685-707.

Li, Y., Audétat, A., 2015. Effects of temperature, silicate melt composition, and oxygen fugacity on the partitioning of V, Mn, Co, Ni, Cu, Zn, As, Mo, Ag, Sn, Sb, W, Au, Pb, and Bi between sulfide phases and silicate melt. Geochim. Cosmochim. Acta 162, 25-45.

Mungall, J.E., Brenan, J.M., Godel, B., Barnes, S.J., Gaillard, F., 2015. Transport of metals and Sulphur in magmas by flotation of sulphide melt on vapour bubbles. Nat. Geosci. 8, 216-219.

Nadeau, O., Williams-Jones, A.E., Stix, J., 2010. Sulphide magma as a source of metals in arc-related magmatic hydrothermal ore fluids. Nat. Geosci. 3, 501-505.

Paonita, A., Federico, C., Bonfanti, P., Capasso, G., Inguaggiato, S., Italiano, F., Madonia, P. Pecoraino, G., Sortino, F., 2013. The episodic and abrupt geochemical changes at La Fossa fumaroles (Vulcano Island, Italy) and related constraints on the dynamics, structure, and compositions of the magmatic system. Geochim. Cosmochim. Acta $120,158-178$.

Parat, F., Holtz, F., Streck, M.J., 2011. Sulfur-bearing magmatic accessory minerals. Rev. Mineral. Geochem. 73, 285-314.

Park, J.-W., Campbell, I.H., Arculus, R.J., 2013. Platinum-alloy and sulfur saturation in an arc-related basalt to rhyolite suite: evidence from the Pual Ridge lavas, the Eastern Manus Basin. Geochim. Cosmochim. Acta 101, 76-95.

Park, J.-W., Campbell, I.H., Kim, J., Moon, J.W., 2015. The role of late sulfide saturation in the formation of a Cu- and Au-rich Magma: Insights from the platinum group element geochemistry of Niuatahi-Motutahi Lavas, Tonga Rear Arc. J. Petrol. 56, 59-81.

Park, J.-W., Campbell, I.H., Malaviarachchi, S.P.K., Cocker, H., Hao, H., Kay, S.M., 2019. Chalcophile element fertility and the formation of porphyry $\mathrm{Cu} \pm$ Au deposits. Mineral. Deposita 54, 657-670.

Peccerillo, A., Frezzotti, M.L., De Astis, G., Ventura, G., 2006. Modeling the magma plumbing system of Vulcano (Aeolian Islands, Italy) by integrated fluid-inclusion geobarometry, petrology, and geophysics. Geology 34, 17-20.

Richards, J.P., 2011. Magmatic to hydrothermal metal fluxes in convergent and collided margins. Ore Geol. Rev. 40, 1-26.

Richards, J.P., 2015. The oxidation state, and sulfur and Cu contents of arc magmas: implications for metallogeny. Lithos 233, 27-45.

Rosi, M., Di Traglia, F., Pistolesi, M., Esposti Ongaro, T., de Michieli Vitturi, M., Bonadonna, C., 2018. Dynamics of shallow hydrothermal eruptions: new insights from Vulcano's Breccia di Commenda eruption. Bull. Volcanol. 80, 8.

Rottier, B., Audétat, A., Kodera, P., Lexa, J., 2019. Origin and evolution of magmas in the porphyry Au -mineralized Javorie volcano (Central Slovakia): evidence from 
2449-2482. https://doi.org/10.1093/petrology/egaa014.

Scaillet, B., MacDonald, R., 2006. Experimental and thermodynamic constraints on the Sulphur yield of peralkaline and metaluminous silicic flood eruptions. J. Petrol. 47, 1413-1437.

Scaillet, B., Pichavant, M., 2005. A model of Sulphur solubility for hydrous mafic melts: application to the determination of magmatic fluid compositions of Italian volcanoes. Ann. Geophys. 48, 671-698.

Sillitoe, R.H., 2010. Porphyry copper systems. Econ. Geol. 105, 3-41.

Timm, C., de Ronde, C.E.J., Leybourne, M.I., Layton-Matthews, D., Graham, I.J., 2012. Sources of chalcophile and siderophile elements in kermadec arc lavas. Econ. Geol. 107, 1527-1538.

Wilkinson, J.J., 2013. Triggers for the formation of porphyry ore deposits in magmatic arcs. Nat. Geosci. 6, 917-925. coefficients by LA-ICPMS analysis of co-existing fluid and silicate melt inclusions: controls on element partitioning. Geochim. Cosmochim. Acta 72, 2169-2197.

Zajacz, Z., Candela, P.A., Piccoli, P.M., Sanchez-Valle, C., 2012. Gold and copper in volatile saturated mafic to intermediate magmas: solubilities, partitioning and implications or ore deposit formation. Geochim. Cosmochim. Acta 91, 140-159.

Zelenski, M., Kamenetsky, V.S., Mavrogenes, J.A., Gurenko, A.A., Danyushevsky, L.V., 2018. Silicate-sulfide liquid immiscibility in modern arc basalt (Tolbachik volcano, Kamchatka): part I. Occurrence and compositions of sulfide melts. Chem. Geol. 478, 102-111.

Zhang, D., Audétat, A., 2017. What caused the formation of the giant bingham canyon porphyry Cu-Mo-Au deposit? Insights from melt inclusions and magmatic sulfides. Econ. Geol. 112, 221-244. 